\title{
Toxin production by Clostridium difficile in a defined medium with limited amino acids
}

\author{
K. YAMAKAWA, S. KAMIYA*, X. O. MENG, T. KARASAWA and S. NAKAMURA $\dagger$ \\ Department of Bacteriology, School of Medicine, Kanazawa University, 13-1 Takara-machi, Kanazawa, \\ Ishikawa 920, Japan
}

\begin{abstract}
Summary. Basal defined medium (BDM) containing vitamins, minerals and seven amino acids- $(/ \mathrm{L})$ tryptophan $0.1 \mathrm{~g}$, methionine $0.2 \mathrm{~g}$, valine $0.3 \mathrm{~g}$, isoleucine $0.3 \mathrm{~g}$, proline $0.3 \mathrm{~g}$, leucine $0.4 \mathrm{~g}$ and cysteine $0.5 \mathrm{~g}$-which appeared to be essential for good growth of Clostridium difficile was prepared. Addition of glycine $0.2 \mathrm{~g} / \mathrm{L}$ and threonine $0.4 \mathrm{~g} / \mathrm{L}$ to BDM produced better growth of strain VPI 10463, and this defined medium was designated minimum amino acid-defined medium (MADM). Production of toxins A and B by strain VPI 10463 in $6 \times$ MADM containing $(/ \mathrm{L})$ tryptophan $0.6 \mathrm{~g}$, methionine $1.2 \mathrm{~g}$, valine $1.8 \mathrm{~g}$, isoleucine $1.8 \mathrm{~g}$, proline $1.8 \mathrm{~g}$, leucine $2.4 \mathrm{~g}$, cysteine $0.5 \mathrm{~g}$, glycine $0.2 \mathrm{~g}$ and threonine $0.4 \mathrm{~g}$, was much greater than in MADM. Toxin production by $20 \mathrm{C}$. difficile strains was examined in two defined media-6 6 MADM and complete amino acid-defined medium (CADM) containing 18 amino acids - and one complex medium, modified brain heart infusion medium (m-BHI). Simultaneous production of toxins A and B by all test strains was demonstrated in $\mathrm{m}$-BHI and the two defined media. It was also shown that $6 \times$ MADM was generally better than CADM and as effective as $\mathrm{m}$-BHI for stimulating toxin production by 13 strains. This defined medium would be useful for studies on the physiology, metabolism and pathogenicity of $C$. difficile.
\end{abstract}

\section{Introduction}

Clostridium difficile causes pseudomembranous colitis and is a major aetiological agent of antibioticassociated diarrhoea. ${ }^{1-4}$ It produces at least two toxins designated toxin A (enterotoxin) and toxin B (cytotoxin), which are considered to be important virulence factors. ${ }^{5-8}$

The composition of the growth medium greatly influences the ability of $C$. difficile to produce these toxins in vitro. ${ }^{9}$ However, little work has been reported on the nutritional requirements for toxin production. Haslam et al. ${ }^{10}$ demonstrated that seven amino acids - tryptophan, methionine, valine, isoleucine, proline, leucine and cysteine-are essential for good growth, and that the amino acids required for toxin production varied between strains.

In the present study, toxin production by $C$. difficile in a defined medium containing the amino acids essential or stimulatory for growth was investigated.

Received 10 May 1994; accepted 25 May 1994

*Present address: Department of Microbiology, School of Medicine, Kyorin University, Shinkawa, Mitaka, Tokyo 181, Japan †Correspondence should be sent to Professor S. Nakamura.

\section{Materials and methods}

\section{Bacterial strains}

Twenty $C$. difficile strains were used in this study. Reference strain VPI 10463 was used to determine the composition and concentration of amino acids required in a defined medium. The other 19 strains had been isolated in our laboratory from healthy adults ( 13 strains) or patients with antibiotic-associated diarrhoea (six strains), ${ }^{11}$ and were tested for toxin production in the proposed medium. Toxin B production in $\mathrm{m}$-BHI medium (see below) was in the range $2^{5}-2^{14} \mathrm{CU} / 50 \mu \mathrm{l}$ in the strains from healthy adults and $2^{6}-2^{13} \mathrm{CU} / 50 \mu \mathrm{l}$ in the strains from symptomatic patients.

\section{Preparation of defined media}

Basal defined medium (BDM) (table) was based on that described by Haslam et al..$^{10}$ with four modifications: $\mathrm{Na}_{2} \mathrm{HPO}_{4}$ was added, $\mathrm{Na}_{2} \mathrm{CO}_{3}$ was replaced with $\mathrm{NaHCO}_{3}$, the concentration of glucose was $0.2 \%$ instead of $0.5 \%$, and 11 amino acids-histidine, glycine, tyrosine, arginine, phenylalanine, threonine, alanine, lysine, serine, aspartic acid and glutamic acid-were omitted. The medium was sterilised by membrane filtration (Millex-HA, pore size, $0.45 \mu \mathrm{m}$; Nihon Millipore, Yonezawa, Japan) and distributed in 
Table. Composition of basal defined medium (BDM) and complete amino acid-defined medium (CADM)

\begin{tabular}{|c|c|c|c|}
\hline Amino acids (g) & & Vitamins (mg) & \\
\hline Tryptophan & $0 \cdot 1$ & Thiamine & 1000 \\
\hline Methionine & $0 \cdot 2$ & Ca-D-pantothenate & 1000 \\
\hline Valine & $0 \cdot 3$ & Nicotinamide & 1000 \\
\hline Isoleucine & $0 \cdot 3$ & Riboflavin & 1000 \\
\hline Proline & $0 \cdot 3$ & Pyridoxine & 1000 \\
\hline Leucine & $0 \cdot 4$ & $p$-Aminobenzoic acid & 50 \\
\hline Cysteine & $0 \cdot 5$ & Biotin & 12.5 \\
\hline Histidine* & 0.1 & Folic acid & 12.5 \\
\hline Glycine* & $0 \cdot 1$ & $\mathrm{~B}_{1}$ & $5 \cdot 0$ \\
\hline Tyrosine* & $0 \cdot 1$ & & \\
\hline Arginine* & 0.2 & Minerals (mg) & \\
\hline Phenylalanine* & 0.2 & $\mathrm{KH}_{2} \mathrm{PO}_{4}$ & 900 \\
\hline Threonine* & 0.2 & $\mathrm{Na}_{2} \mathrm{HPO}_{4}$ & 5000 \\
\hline Alanine* & 02 & $\mathrm{NaCl}$ & 900 \\
\hline Lysine* & $0 \cdot 3$ & $\mathrm{CaCl}_{2} \cdot 2 \mathrm{H}_{2} \mathrm{O}$ & 26 \\
\hline Serine* & $0 \cdot 3$ & $\mathrm{MgCl}_{2} \cdot 6 \mathrm{H}_{2} \mathrm{O}$ & 20 \\
\hline Aspartic acid* & 0.3 & $\mathrm{MnCl}_{2} \cdot 4 \mathrm{H}_{2} \mathrm{O}$ & 10 \\
\hline \multirow{4}{*}{ Glucose $(\mathrm{g})$} & $0 \cdot 9$ & $\begin{array}{l}\left(\mathrm{NH}_{4}\right)_{2} \mathrm{SO}_{4} \\
\mathrm{FeSO}_{4} \cdot 7 \mathrm{H}_{2} \mathrm{O}\end{array}$ & $\begin{array}{r}40 \\
4\end{array}$ \\
\hline & $2 \cdot 0$ & $\mathrm{CoCl}_{2} \cdot 6 \mathrm{H}_{2} \mathrm{O}$ & 1 \\
\hline & & $\mathrm{NaHCO}_{3}$ & 5000 \\
\hline & & Distilled water (L) & 1 \\
\hline
\end{tabular}

*Amino acids contained in CADM but not in BDM

10 -ml amounts in test tubes $(15 \times 160 \mathrm{~mm})$ flushed with oxygen-free gas $\left(\mathrm{H}_{2} 10 \%, \mathrm{CO}_{2} 10 \%, \mathrm{~N}_{2} 80 \%\right)$. The tubes were then stoppered with rubber stoppers. Complete amino acid-defined medium (CADM) containing all 18 amino acids was also prepared as described above. Modified Brain Heart Infusion Broth (m-BHI) was prepared according to the description by Nakamura et al."2

\section{Inoculation and incubation}

Standard suspensions for inoculation were prepared after growth of $C$. difficile in liver broth for $24 \mathrm{~h}$ at $37^{\circ} \mathrm{C}$. The cultures were centrifuged at $1500 \mathrm{~g}$ for $20 \mathrm{~min}$ and washed twice with pre-reduced saline. The final pellets were resuspended in the original volumes of saline and used as inocula.

To determine the growth-enhancing amino acids for strain VPI 10463, $0.1 \mathrm{ml}$ of the suspension was inoculated into $10 \mathrm{ml}$ of BDM supplemented with one of the specified amino acids at the concentration shown in the table. The cultures were then incubated at $37^{\circ} \mathrm{C}$ and bacterial growth was measured every $2 \mathrm{~h}$.

For investigation of toxin production, $10 \mathrm{ml}$ of various test media were inoculated with $0.1 \mathrm{ml}$ of the inoculum suspension and incubated for $16 \mathrm{~h}$ at $37^{\circ} \mathrm{C}$. The cultures were diluted 1000-fold in pre-reduced saline and $0.1 \mathrm{ml}$ of the diluted culture was used for inoculation of $10-\mathrm{ml}$ volumes of the various test media. Thus, the carry-over of liver broth into a test medium was negligible. The cultures were incubated at $37^{\circ} \mathrm{C}$ for 5 days in anaerobic conditions and culture supernates were collected by centrifugation. The supernates were sterilised by membrane filtration (Millex-GV, pore size, $0.22 \mu \mathrm{m}$; Nihon Millipore) and used for the toxin assays.

\section{Bacterial growth}

Bacterial growth was determined by measuring the optical density of cultures at $560 \mathrm{~nm}\left(\mathrm{OD}_{560}\right)$ with a Shimadzu-Bosch-Lomb Spectronic 20A spectrophotometer (Shimadzu, Kyoto, Japan).

\section{Toxin assays}

Toxin A was quantified by the direct sandwich enzyme-linked immunosorbent assay (ELISA) as described by Redmond et al. ${ }^{13}$ The minimum concentration of toxin A measurable in this assay was $10 \mathrm{ng} / \mathrm{ml}$.

Toxin B titres were determined by a conventional cytotoxicity test with BHK-21/WI-2 cells. ${ }^{12}$ After twofold serial dilution of unconcentrated culture filtrates, each diluted sample was added to BHK-21/WI-2 cells. The cytotoxic titre was the maximum dilution that gave $100 \%$ cell rounding after incubation for $24 \mathrm{~h}$.

\section{Results}

\section{Determination of growth-enhancing amino acids}

Growth of strain VPI 10463 in BDM was considerably poorer than that in CADM; the maximum $\mathrm{OD}_{560}$ values were 0.60 in $\mathrm{BDM}$ and 0.88 in CADM, and the incubation time required to reach these values was $14 \mathrm{~h}$ in BDM and $9 \mathrm{~h}$ in CADM.

To identify the growth-enhancing amino acids, growth of strain VPI 10463 in BDM supplemented with one of 11 amino acids, which were contained in CADM but not in BDM, was examined; threonine and glycine enhanced growth considerably. In BDM supplemented with threonine, maximum growth $\left(\mathrm{OD}_{560} 0.75\right)$ was reached after incubation for $11 \mathrm{~h}$ (fig. 1). In BDM supplemented with glycine, significantly increased growth was observed from 4 to $14 \mathrm{~h}$ after inoculation in comparison to growth in $B D M$ although the maximum $\mathrm{OD}_{560}$ value was not markedly increased. Two-fold greater concentration of these amino acids did not show any further effect.

\section{Toxin production in defined media}

BDM and BDM supplemented with threonine $0.4 \mathrm{~g} / \mathrm{L}$ and glycine $0.2 \mathrm{~g} / \mathrm{L}$ (minimum amino aciddefined medium; MADM) were compared for toxin production by strain VPI 10463. The amounts of both toxins produced were approximately two-fold more in MADM than in BDM; the amounts of toxins A and B were $440 \mathrm{ng} / \mathrm{ml}$ and $22^{13} \mathrm{CU} / 50 \mu \mathrm{l}$ in $\mathrm{BDM}$, and $980 \mathrm{ng} / \mathrm{ml}$ and $2^{14} \mathrm{CU} / 50 \mu 1$ in MADM, respectively.

The concentrations of six essential amino acidstryptophan, methionine, valine, isoleucine, proline and 


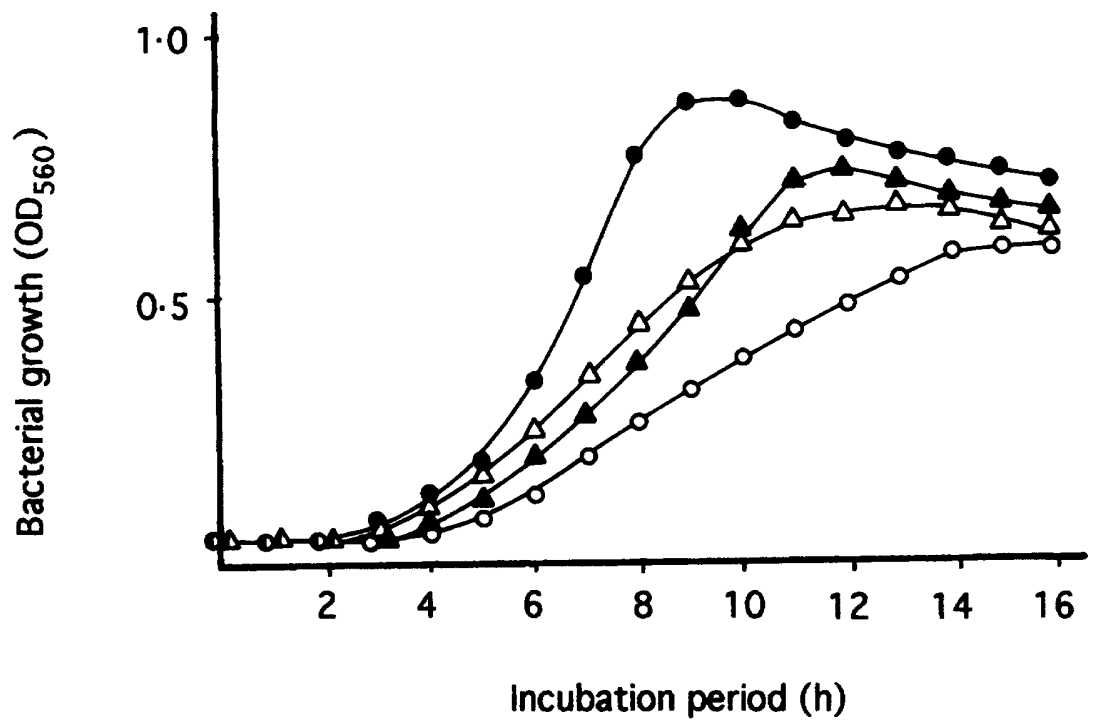

Fig. 1. Effect of glycine $0.1 \mathrm{~g} / \mathrm{L}(\triangle)$ and threonine $0.2 \mathrm{~g} / \mathrm{L}(\boldsymbol{\Delta})$ on the growth of $C$. difficile strain VPI 10463 in BDM; $\bigcirc$, no amino acid supplement;, CADM.

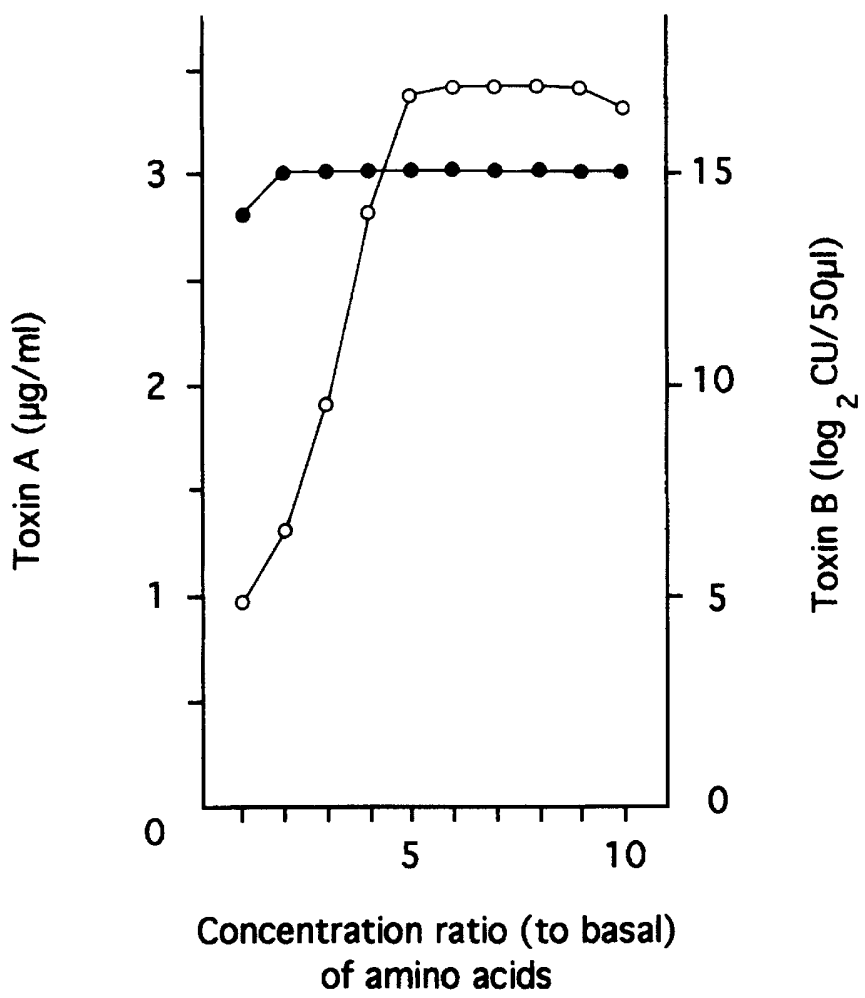

Fig. 2. Effect of increments of amino acids on toxin production of toxins A $(O)$ and B (O) by C. difficile strain VPI 10463 in MADM. Basal concentration of amino acids $(\mathrm{g} / \mathrm{L})$ : tryptophan, 0.1 ; methionine, 0.2 ; valine, 0.3 ; isoleucine, 0.3 ; proline, $0.3 ;$ leucine, 0.4 ; glycine, 0.2 ; threonine, $0 \cdot 4$; cysteine, $0 \cdot 5$. Concentrations of amino acids except for glycine, threonine and cysteine were increased.

leucine-in MADM were increased up to 10 times those in BDM to determine their relationship with toxin production. The amount of toxin $\mathrm{A}$ increased in parallel with the increase in concentrations of these amino acids, reaching a maximum $(3360 \mathrm{ng} / \mathrm{ml})$ when five times the basal concentrations of the amino acids were used (fig. 2). In contrast, the amount of toxin B reached a maximum $\left(2^{15} \mathrm{CU} / 50 \mu \mathrm{l}\right)$ when twice the basal concentrations of the amino acids were used. Bacterial growth did not fluctuate in the range of concentrations tested; the maximum $\mathrm{OD}_{560}$ values were $0 \cdot 41-0 \cdot 48$.

On the basis of these findings, a defined medium $(6 \times$ MADM) containing $(\mathrm{g} / \mathrm{L})$ tryptophan $0 \cdot 6$, methionine $1 \cdot 2$, valine $1 \cdot 8$, isoleucine $1 \cdot 8$, proline $1 \cdot 8$, leucine 2.4 , glycine 0.2 , threonine 0.4 and cysteine 0.5 was prepared and compared with $\mathrm{m}-\mathrm{BHI}$ and CADM with respect to toxin production.

All 20 test strains produced detectable amounts of toxin B in any medium, although the titres of the toxin 


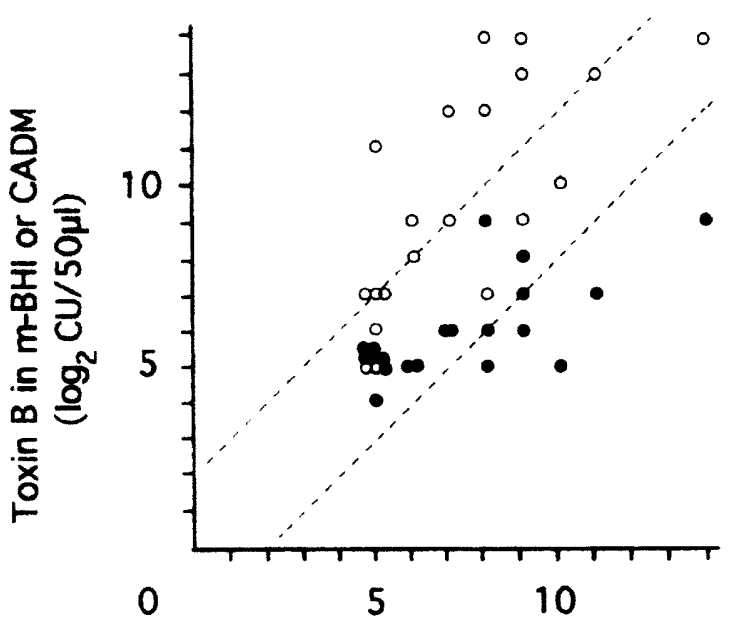

Toxin $B$ in 6xMADM $\left(\log _{2} \mathrm{CU} / 50 \mathrm{Hl}\right)$

Fig. 3. Comparison of toxin $\mathrm{B}$ production by $C$. difficile strains in $6 \times$ MADM to that in $\mathrm{m}-\mathrm{BHI}(\mathrm{O})$ or CADM (O). Difference of toxin $\mathrm{B}$ titres between $\mathrm{m}-\mathrm{BHI}$ and $6 \times \mathrm{MADM}$, or CADM and $6 \times$ MADM, for individual strains shown between two dashed lines was less than four-fold

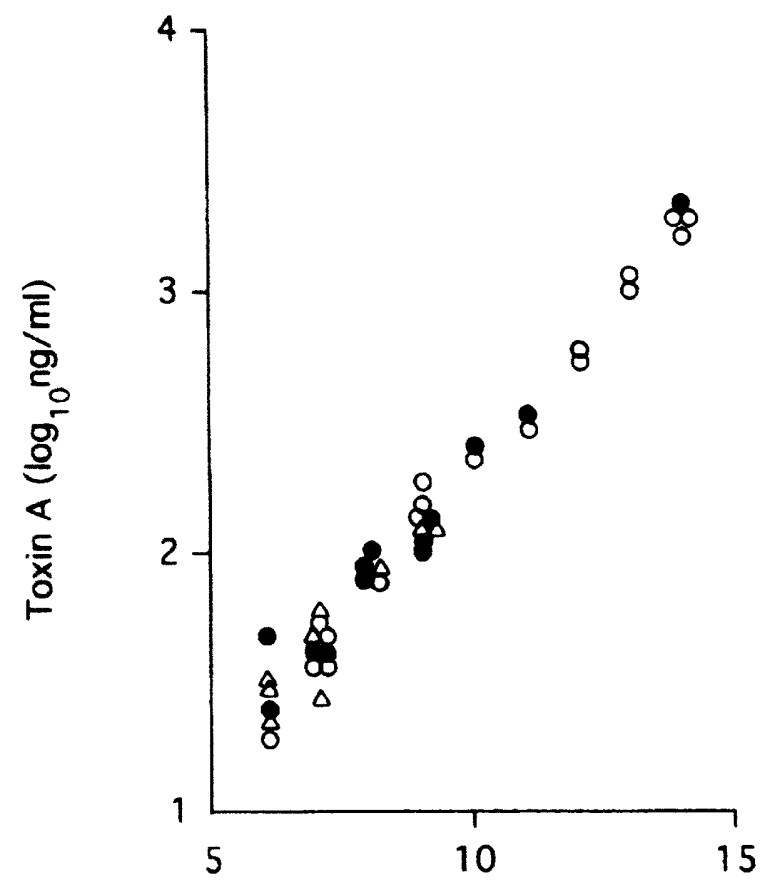

Toxin B $\left(\log _{2} \mathrm{CU} / 50 \mu \mathrm{l}\right)$

Fig. 4. Correlation between production of toxins $\mathrm{A}$ and $\mathrm{B}$ by $C$. difficile strains in $\mathrm{m}-\mathrm{BHI}(\mathrm{O}), 6 \times$ MADM $(\bullet)$ and CADM $(\triangle)$. The regression equation gave: $\mathrm{m}-\mathrm{BHI}, \mathrm{Y}=0.23 \mathrm{X}-0.01, \mathrm{r}=0.99$, $n=18: 6 \times$ MADM $, Y=0 \cdot 22 X+0 \cdot 12 . r=0 \cdot 98, n=13: C A D M$ $\mathrm{Y}=0.21 \mathrm{X}+0.02 . \mathrm{r}=0.98, \mathrm{n}=9$.

varied among the three media. As there was a correlation between production of toxins $\mathrm{A}$ and $\mathrm{B}$ in all three media tested as described below, the three media were evaluated according to the titres of toxin B (fig. 3).

In a comparison of $6 \times$ MADM and $\mathrm{m}-\mathrm{BHI}, 13$ strains did not produce significantly different amounts of toxin B: differences in the titres between the two media for individual strains were less than four-fold. In a comparison of $6 \times$ MADM and CADM, it was observed generally that $6 \times$ MADM was more effective than CADM for stimulating toxin B production. Five strains produced eight times more toxin $B$ in $6 \times$ MADM than in CADM, and none of the strains produced eight times more toxin $\mathrm{B}$ in $\mathrm{CADM}$ than in $6 \times$ MADM.

Toxin A was detected with the ELISA employed in this study in all cultures in which the titre of toxin B was $\geqslant 2^{6} \mathrm{CU} / 50 \mu \mathrm{l}$. Therefore, correlation between production of toxins $\mathrm{A}$ and $\mathrm{B}$ in the respective media was analysed for the strains producing toxin $B$ at $\geqslant 2{ }^{6} \mathrm{CU} / 50 \mu \mathrm{l}$ (fig. 4); 18 strains were used for the analysis in $\mathrm{m}-\mathrm{BHI}, 13$ in $6 \times \mathrm{MADM}$, and nine in CADM. All the strains produced both toxins in parallel concentrations in defined media $(6 \times$ MADM and CADM) and in the complex medium (m-BHI). These results indicate that the strains producing toxin B at $<2^{6} \mathrm{CU} / 50 \mu \mathrm{l}$ may also produce toxin $\mathrm{A}$. When $6 \times$ MADM culture supernatant fluids of six strains that produced undetectable amounts of toxin $\mathrm{A}$ and $2^{5} \mathrm{CU}$ of toxin $\mathrm{B} / 50 \mu \mathrm{l}$ were concentrated with polyethylene glycol 20000 (resulting in a toxin B titre of $\left.2^{8-9} \mathrm{CU} / 50 \mu \mathrm{l}\right), \quad 96-190 \mathrm{ng}$ of toxin $\mathrm{A} / \mathrm{ml}$ were detected.

\section{Discussion}

Haslam et al. ${ }^{10}$ demonstrated that seven amino acids-tryptophan, methionine, valine, isoleucine, proline, leucine and cysteine-were essential for good growth of $C$. difficile. Therefore, a medium composed of these seven amino acids was used as BDM in the studies. Bacterial growth in BDM was enhanced by the addition of glycine or threonine, although the maximum growth was slightly less than that in CADM containing 18 amino acids. It is possible that some amino acids other than glycine and threonine may enhance bacterial growth to a level which is not detected by the methods employed here.

Cysteine is commonly used at a concentration of $0.05 \%$ as a reducing agent in anaerobic culture; it inhibits bacterial growth at higher concentrations. ${ }^{14}$ Therefore, various concentrations of the six essential amino acids except for cysteine were examined for stimulation of toxin production by $C$. difficile. Maximum production of toxins $A$ and $B$ was observed when five-to-nine times more amino acids were added to BDM. It remains to be determined which amino acid is the most effective for stimulating toxin production by C. difficile.

Haslam et al. ${ }^{10}$ reported that weakly toxigenic strains may require some amino acids for production of toxin $\mathrm{A}$, in addition to those essential for bacterial growth. The strains tested in this study varied widely in toxigenicity as determined in $\mathrm{m}-\mathrm{BHI}$; the titre of toxin $A$ ranged between $<10$ and $3360 \mathrm{ng} / \mathrm{ml}$ and that of toxin B between $2^{5}$ and $2^{16} \mathrm{CU} / 50 \mu \mathrm{l}$. However, all 20 
strains tested produced both toxins $\mathrm{A}$ and $\mathrm{B}$ in a defined medium, $6 \times$ MADM, composed of seven essential and two amino acids that stimulated growth. Furthermore, five strains produced distinctively larger amounts of toxins in $6 \times$ MADM than in CADM. This may be due to differences between the strains tested at high concentrations of amino acids. Recently, it was reported that the concentration of arginine or tryptophan markedly affects the production of neurotoxin by group I or type $\mathrm{E}$ strains of $C$. botulinum, respectively. ${ }^{15,16}$

In complex media such as m-BHI, toxigenic $C$. difficile strains, with some exceptions, generally produced both toxins A and B in parallel concentrations. ${ }^{17-19}$ This correlation was also found when the defined medium, $6 \times$ MADM was used, indicating that amino acids included in this medium are sufficient for the production of both toxins as far as the strains tested are concerned.

Toxins A and B are encoded by two separate genes located in close proximity on the chromosome. ${ }^{20,21}$

\section{References}

1. Bartlett JG, Chang TW, Gurwith M, Gorbach SL, Onderdonk AB. Antibiotic-associated pseudomembranous colitis due to toxin-producing clostridia. $N$ Engl $J$ Med 1978; 298: 531-534.

2. George WL, Sutter VL, Goldstein EJC, Ludwig SL, Finegold SM. Aetiology of antimicrobial-agent-associated colitis. Lancet 1978; 1 : 802-803.

3. Larson HE, Price AB, Honour P, Borriello SP. Clostridium difficile and the aetiology of pseudomembranous colitis. Lancet 1978; 1: 1063-1066.

4. Borriello SP, Larson HE. Antibiotic and pseudomembranous colitis. J Antimicrob Chemother 1981; 7 Suppl A: 53-65.

5. Sullivan NM, Pellett S, Wilkins TD. Purification and characterization of toxins A and B of Clostridium difficile. Infect Immun 1982; 35: 1032-1040.

6. Banno Y, Kobayashi T, Kono H, Watanabe K, Ueno K, Nozawa $Y$. Biochemical characterization and biologic actions of two toxins (D-1 and D-2) from Clostridium difficile. Rev Infect Dis 1984; 6 Suppl 1: S11-S20.

7. Lyerly DM, Roberts MD, Phelps CJ, Wilkins TD. Purification and properties of toxins $\mathrm{A}$ and $\mathrm{B}$ of Clostridium difficile. FEMS Microbiol Lett 1986; 33: 31-35.

8. Lyerly DM, Krivan HC, Wilkins TD. Clostridium difficile: its disease and toxins. Clin Microbiol Rev 1988; 1: 1-18.

9. Rolfe RD, Finegold SM. Purification and characterization of Clostridium difficile toxin. Infect Immun 1979; 25: 191-201.

10. Haslam SC, Ketley JM, Mitchell TJ, Stephen J, Burdon DW, Candy DCA. Growth of Clostridium difficile and production of toxins A and B in complex and defined media. $J$ Med Microbiol 1986; 21 : 293-297.

11. Nakamura S, Nakashio S, Mikawa M, Yamakawa K, Okumura S, Nishida S. Antimicrobial susceptibility of Clostridium difficile from different sources. Microbiol Immunol 1982; 26: $25-30$.

12. Nakamura S, Mikawa M, Nakashio $\mathbf{S}$ et al. Isolation of Clostridium difficile from feces and the antibody in sera of young and elderly adults. Microbiol Immunol 1981; 25 : 345-351.

13. Redmond SC, Ketley JM, Mitchell TJ, Stephen J, Burdon DW, Candy DCA. Detection of Clostridium difficile enterotoxin. In: Collins CH, Grange JM (eds) Isolation and identification of micro-organisms of medical and veterinary im-
Toxigenic strains with both toxin A and toxin B genes generally produce both toxins simultaneously. ${ }^{22.23}$ This suggests that simultaneous expression of the two toxins is due to the presence of both genes, although the unusual toxin A-negative, toxin B-positive strain was reported recently to have a whole toxin $B$ gene and an incomplete toxin $\mathrm{A}$ gene. ${ }^{24,25}$ The correlation between the levels of toxin A and toxin B produced also indicates that expression of both toxin genes may be regulated in the defined medium in the same manner as in the complex medium.

Considering that nearly half of the strains tested produced fairly large amounts of both toxins, the defined medium developed in this study will be useful for studies on the physiology, metabolism and pathogenicity of $C$. difficile, and particularly for the study of various environmental factors affecting the expression of toxin genes.

This work was supported in part from the fund for medical treatment of the elderly, School of Medicine, Kanazawa University, 1992.

portance. Society of Applied Bacteriology, Technical Series No. 21. Academic Press, London. 1985: 237-250.

14. Smith LDS. The pathogenic anaerobic bacteria, 2nd edn. Springfield, Charles C. Thomas. 1975: 3-14.

15. Patterson-Cirtis SI, Johnson EA. Regulation of neurotoxin and protease formation in Clostridium botulinum Okra B and Hall A by arginine. Appl Environ Microbiol 1989; 55: 1544-1548.

16. Leyer GL, Johnson EA. Repression of toxin production by tryptophan in Clostridium botulinum type E. Arch Microbiol 1990 ; 154: 443-447.

17. Lyerly DM, Sullivan NM, Wilkins TD. Enzyme-linked immunosorbent assay for Clostridium difficile toxin A. J Clin Microbiol 1983; 17: 72-78.

18. Laughon BE, Viscidi RP, Gdovin SL, Yolken RH, Bartlett JG. Enzyme immunoassays for detection of Clostridium difficile toxins A and B in fecal specimens. J Infect Dis 1984; 149: 781-788.

19. Wren BW, Heard SR, Tabaqchali S. Association between production of toxins A and B and types of Clostridium difficile. J Clin Pathol 1987; 40: 1397-1401.

20. Dove CH, Wang S-Z, Price SB et al. Molecular characterization of the Clostridium difficile toxin A gene. Infect Immun 1990; 58: $480-488$.

21. Johnson JL, Phelps C, Barroso L, Roberts MD, Lyerly DM, Wilkins TD. Cloning and expression of the toxin $B$ gene of Clostridium difficile. Curr Microbiol 1990; 20: 397-401.

22. Fluit AC, Wolfhagen MJHC, Verdonk GPHT, Jansze M, Torensma R, Verhoef J. Nontoxigenic strains of Clostridium difficile lack the genes for both toxin $\mathrm{A}$ and toxin B. J Clin Microbiol 1991; 29: 2666-2667.

23. McMillin DE, Muldrow LL, Leggette SJ, Abdulahi Y, Ekanemesang UM. Molecular screening of Clostridium difficile toxins $\mathrm{A}$ and $\mathrm{B}$ genetic determinants and identification of mutant strains. FEMS Microbiol Lett 1991; 78: 75-80.

24. Borriello SP, Wren BW, Hyde S et al. Molecular, immunological, and biological characterization of a toxin Anegative, toxin B-positive strain of Clostridium difficile. Infect Immun 1992; 60: 4192-4199.

25. Lyerly DM, Barroso LD, Wilkins TD, Depitre C, Corthier G. Characterization of a toxin A-negative, toxin B-positive strain of Clostridium difficile. Infect Immun 1992; 60: 4633-4639. 